Ann. Génét. Sél. anim., 1978, 10 (1), 47-60.

\title{
Genetic and phenotypic parameters of egg production and some constituents of blood serum in Fayoumi layers
}

\author{
A. OBEIDAH, H. M. MORAD $(*)$, A. A. SAMI and A. MOSTAGEER \\ Animal Breeding Department, Faculty of Agriculture, Cairo University, Giza (Egypt) \\ $\left({ }^{*}\right)$ Faculty of Veterinary Medecine, Alexandria University
}

\section{Summary}

Out of 9 hatches, a total of 439 Fayoumi layers, ranging in age between 12 and I 9 months, was used to study (I) egg production beside the following blood serum constituents: (2) inorganic phosphorus, (3) calcium, (4) glucose, (5) urea, (6) uric acid, (7) total proteins, (8) albumen, (9) cholesterol, (IO) bilirubin, (I I) alkaline phosphatase, (I 2) lactic dehydrogenase and (I3) transaminase. These layers were the daughters of 40 sires and $24 \mathrm{I}$ dams. Blood serum analyses were done using the Sequential Multiple Auto-Analyser, SMA-I2/6o. The least squares mean of the number of eggs produced per layer till 70 weeks of age was 78 . The least squares means of the forementioned blood serum traits were in respective order: (z) $5.55 \mathrm{mg} \mathrm{p}$. I $00,(3) 2 \mathrm{I} .62 \mathrm{mg}$ p. Ioo, (4) I96 mg p. Ioo, (5) $3.96 \mathrm{mg}$ p. Ioo, (6) $5.66 \mathrm{mg}$ p. Ioo, (7) $5.93 \mathrm{mg}$ p. I Oо, (8) 0.71 mg p. Iоo, (9) I67.4 $\mathrm{mg}$ p. IOO, (Iо) $0.36 \mathrm{mg} \mathrm{p.} \mathrm{IOO,} \mathrm{(I} \mathrm{I)} \mathrm{I.023} \mathrm{mu} / \mathrm{ml}$, (I 2) $667 \mathrm{mu} / \mathrm{ml}$, (I3) I69.7 $\mathrm{mu} / \mathrm{ml}$,

Hatch showed statistically significant effects on all the characters studied except inorganic phosphorus, uric acid, total proteins and cholesterol. Age of the layer significantly affected all the blood serum traits except inorganic phosphorus, uric acid and total proteins.

Data were corrected for hatch effects, and, in case of the plasma traits, for age effect, before performing the hierarchical analyses of variances and covariances to evaluate heritabilities, genetic and phenotypic correlations. The combined heritability estimates of the characters studied were in respective order: (I) $0.224 \pm 0.136,(2)-0.057 \pm 0.124,(3) 0.656 \pm 0.226$, (4) $0.639 \pm 0.224$, (5) $0.40 \mathrm{I} \pm 0.195$, (6) $0.752 \pm 0.236$, (7) o.II4 \pm O.I54, (8) $0.56 \mathrm{I} \pm 0.2 \mathrm{I} 5$, (9) $0.197 \pm 0.168$, (I 0 ) o.I $87 \pm 0.166$, (I I) $0.732 \pm 0.234$, (I2) $0.625 \pm 0.223$, (I3) $0.622 \pm 0.222$.

Significant genetic correlations (of at least \pm 0.7 ) were found between egg production and all the blood serum traits except inorganic phosphorus and total proteins.

\section{Introduction}

Information on the genetics of the blood serum constituents in chicken may be valuable in breeding for high productivity. Some of the results reported indicate positive relationship between egg production and serum alkaline phosphatase 
(Gutowska, Parkhurst, Parrot and Verberg, i943; and Wilcox, Vanvleck and SHAFFNER, I962). Wilcox (Ig66) selected for high level of alkaline phosphatase and found the egg production of the high line to be higher than the control in four generations out of five. Genetic relationship between serum alkaline phosphatase and body weight in chicken was studied by Matsumoto, Tonoue and Okada (I960), Okada and Tsutsumi (I963) and Wilcox, Vanvlack and Harvey (I g63).

This experiment was undertaken to obtain information on blood serum constituents of the Fayoumi layers: their means, heritabilities and the genetic and phenotypic correlations between them, together with their relationships with egg production.

\section{Material and methods}

This work was carried out in the Poultry Breeding Farm, Faculty of A griculture, Cairo University. A total of 439 Fayoumi layers produced in nine biweekly hatches starting $\mathrm{I}^{\text {st }}$ February and ending $3^{\text {st }}$ May $\mathrm{I} 974$, was used for this study. These layers represent 40 sire families and 24I dam families. Samples of blood were collected from the birds for chemical analysis during June, July and August I975. The age of layers when blood samples were taken averaged about 70 weeks (488 days). About $7 \mathrm{~cm}^{3}$ of blood from each bird were taken from the wing vein in the morning (between 8 and ro o'clock) before feeding. Blood was kept at $37^{\circ} \mathrm{C}$ for 30 minutes and the serum was separated by centrifuging at $3,000 \mathrm{rpm}$ for 20 minutes. Sera were analysed within two weeks of blood collection using the Sequential Auto-Analyser, SMA-r2/6o, of the Sahil Hospital, Cairo. Traits determined in the blood serum shall be treated in three groups:

Group I : includes the following chemical and non-protein-nitrogen traits: inorganic phosphorus, calcium, glucose, urea and uric acid.

Group 2 : includes the plasma proteins (total proteins and albumen), cholesterol and bilirubin.

Group 3 : includes three of the blood serum enzymes, namely, alkaline phosphatase, lactic dehydrogenase and transaminase.

Egg production of the layers was taken as the number of eggs produced till the age of 70 weeks.

For statistical analysis, the model for each of the blood serum traits was taken as:

$x_{i j}=\mu+a_{i}+b\left(y_{i j}-\overline{\mathrm{Y}}\right)+e_{i j}$, where;

$x_{i j}=$ the observation on the $j^{\text {th }}$ individual of the $i^{\text {th }}$ hatch group,

$\mu=$ overall mean of $x_{i j}$ when equal subclass numbers exist,

$a_{i}=$ the effect of the $i^{\text {th }}$ hatch group,

$b=$ partial regression coefficient of $x$ on age of layer,

$y_{i j}=$ age of the $j^{\text {th }}$ layer of the $i^{\text {th }}$ hatch group,

$\mathrm{Y}=$ the mean of the $y_{i j}$ and

$e_{i j}=$ random error.

The same model, after dropping the regression term, was used for egg production. The overall means and the hatch means beside the partial regression coefficients were fitted by the least-squares analysis (HARVEY, I960). 
It may be of interest to note that the cycle of egg formation was thought first to be one of the factors affecting the blood serum traits. This cycle was measured by the time the hen lays its egg within the 24 hours following blood sampling. However, this factor proved to be statistically insignificant and explained almost nothing of the variance in all the serum traits without exception, and thus was dropped from the model.

Data were corrected for hatch effects and, in case of the plasma traits, for age effect. The hierarchical analyses of variances and covariances were then done on the corrected data to compute the heritabilities of the characters and the genetic and phenotypic correlations between them. The coefficient of the dam component of variance was 1.760 in the M.S. between dams within sires and 2.128 in the M.S. between sires. The coefficient of the sire component of variance in the M.S. between sires was I0.943. Heritabilities and genetic correlations were estimated using combined sire plus dam components.

\section{Results and discussion}

\section{I. - The means}

The overall means ( \pm S.E.) and the means of the nine hatches ( \pm S.E. $)$ for egg production and the three groups of blood serum characters studied, beside the partial regression coefficients $( \pm$ S.E.) on age at blood sampling are given in Tables $I, 3$ and 5 . The analyses of variances of these characters are shown in Tables 2,4 and 6 .

Estimates of the means of the blood serum traits studied have been reported by Shimer (I937), STURkie and Newman (I95I), TAPPer and Kare (I960), MCDANIEl, and Chute (I96I), Wilcox (I966), Weiss, Johnson and NABER (I967), EsTep, FANGUY and FERGUSON (I969), Beli, and FreEman (I97I), STURKie (I976) and others. Whenever estimates are comparable, it can be seen that the Fayoumi means are not much different from those reported in different breeds.

Highly significant effects of hatch are clear in all characters except inorganic phosphorus, uric acid, total proteins and Cholesterol. Late hatches showed in general lower means than earlier hatches. This was clear in all the characters significantly affected by hatch except calcium and lactic dehydrogenase, in which the means increased in the late hatches.

The regression on age at blood sampling showed significant effects on nine of the blood serum traits and had no effect only on inorganic phosphorus, uric acid and total proteins (hatch had no effect also on these three traits). Examining the sign of the regression coefficients, it can be seen that the level of calcium and lactic dehydrogenase in the blood serum increased by the advancement of age, while the levels of the other seven serum traits affected significantly by age, decreased. The amount of variance explained by regression in each of the nine traits affected by age is tremendous indeed. This would suggest that, for genetic studies of these blood serum characters, age must be corrected for, even within the range of layer ages of this study (ca I2-I9 months). 


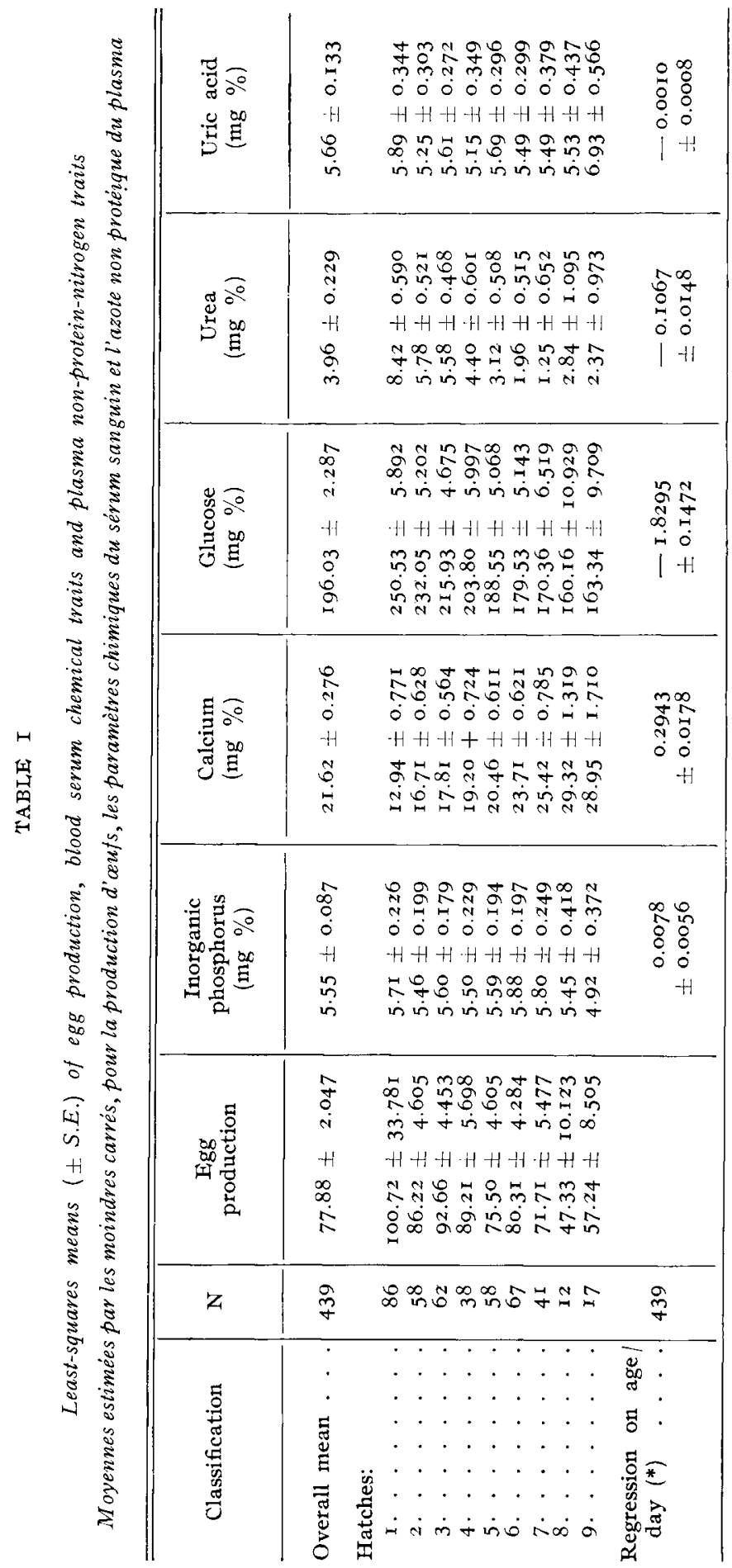




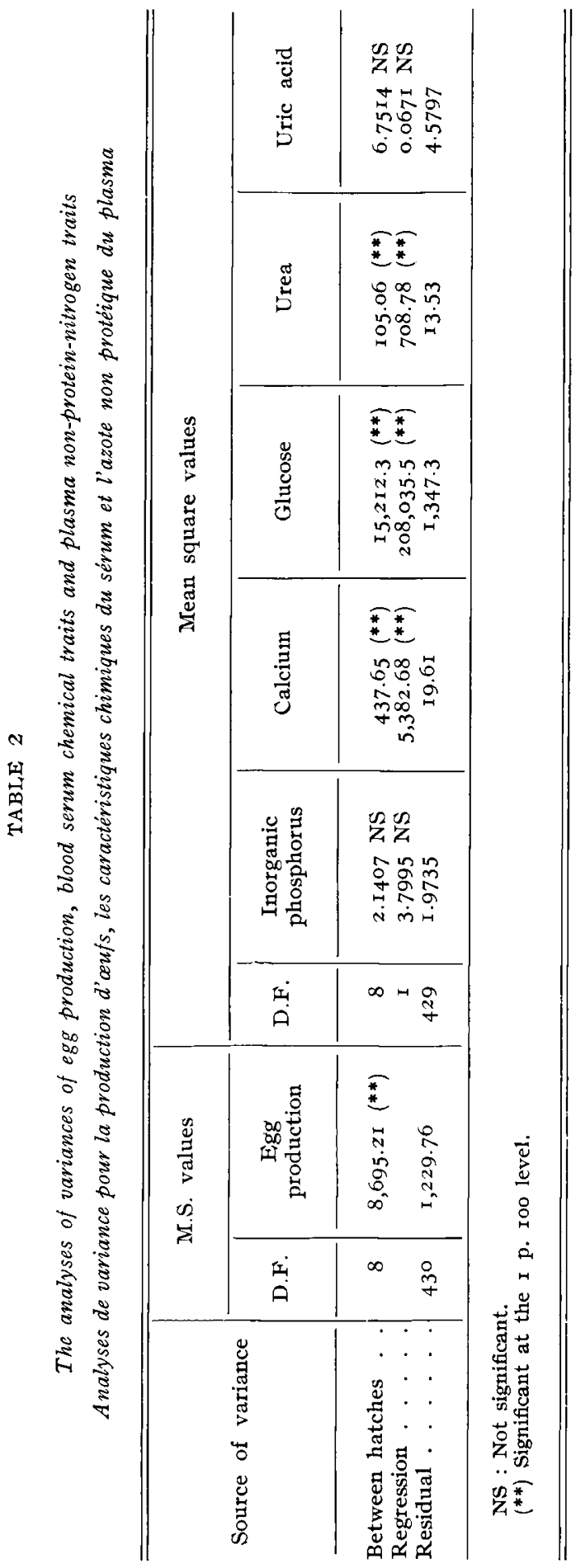


TABLE 3

Least-squares means (亡 S.E.) of plasma proteins, cholesterol and bilirubin Moyennes estimées par les moindres carrés, pour les protéines du plasma, le cholestérol et la bilirubine

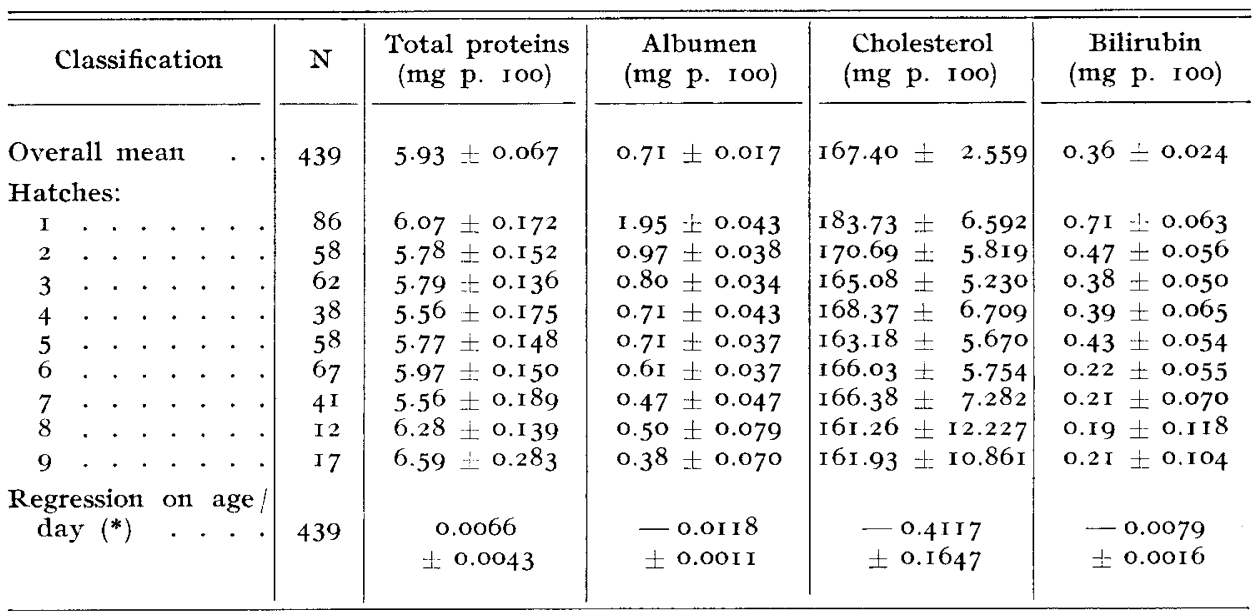

(*) Keeping the other variable (hatch) constant.

TABLE 4

The analyses of variances of plasma proteins, cholesterol and bilirubin Analyses de variance pour les protéines du plasma, le cholestérol et la bilirubine

\begin{tabular}{|c|c|c|c|c|c|}
\hline \multirow{2}{*}{ Source of variance } & \multirow{2}{*}{ D.F. } & \multicolumn{4}{|c|}{ Mean square values } \\
\hline & & Total proteins & Albumen & Cholesterol & Bilirubin \\
\hline Between hatches & 8 & $2.9848 \mathrm{NS}$ & $\mathrm{I} .048 \mathrm{I} \quad(* *)$ & $\mathrm{I}, 36 \mathrm{I} \cdot 33 \mathrm{NS}$ & $0.6 \mathrm{I} 6 z \quad(* *)$ \\
\hline Regression . . . & I & $2.7340 \mathrm{NS}$ & $8.6959(* *)$ & I0,536.65 (**) & $3.9746(* *)$ \\
\hline Residual . . . . & 429 & I. I 460 & 0.0708 & I, 686.37 & O.I 559 \\
\hline
\end{tabular}

NS : Not significant.

(**) Significant at the I p. Ioo level.

\section{II. - Genetic and phenotypic parameters}

a) Egg production and group $I$ of the serum traits:

The heritability values of egg production and group I of the serum traits beside the genetic and phenotypic correlations between them are given in Table 7. The genetic variance of inorganic phosphorus was negative and thus all the genetic 
TABLE 5

Least-squares means ( \pm S.E.) of the three plasma enzymes studied Moyennes estimées par les moindres carrés pour les trois enzymes plasmatiques étudiés

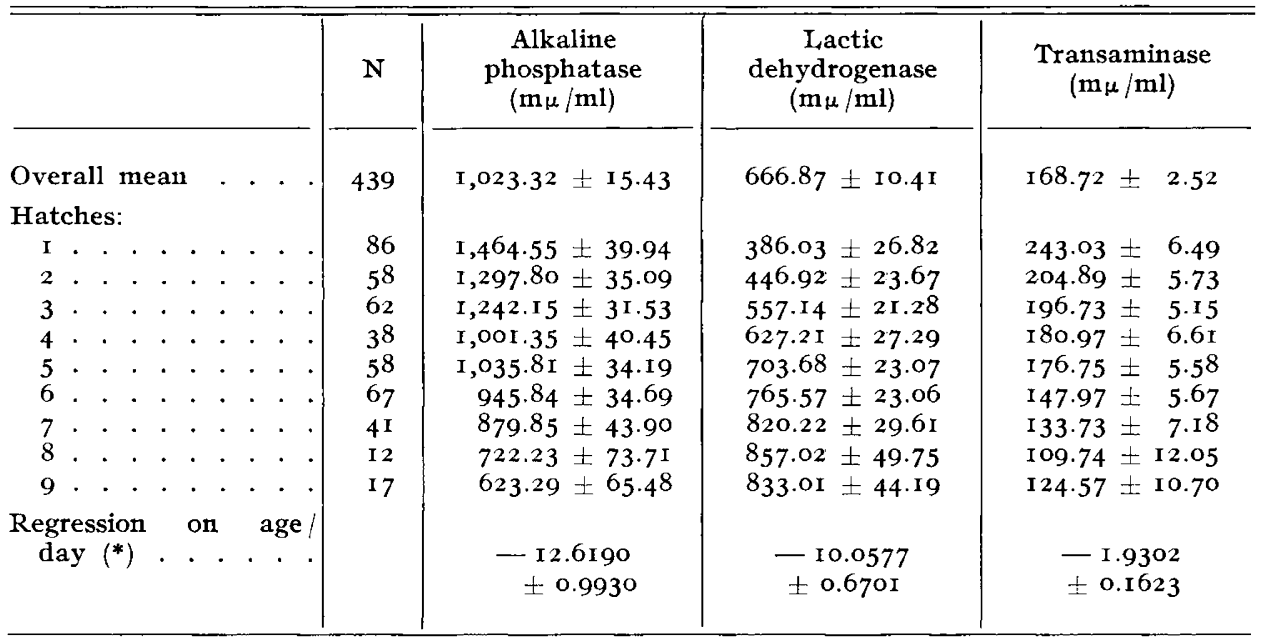

(*) Keeping the other variable (hatch) constant.

\section{TABLE 6}

The analyses of variances of the three plasma enzymes studied

Analyses de variance pour les trois enzymes plasmatiques étudiés

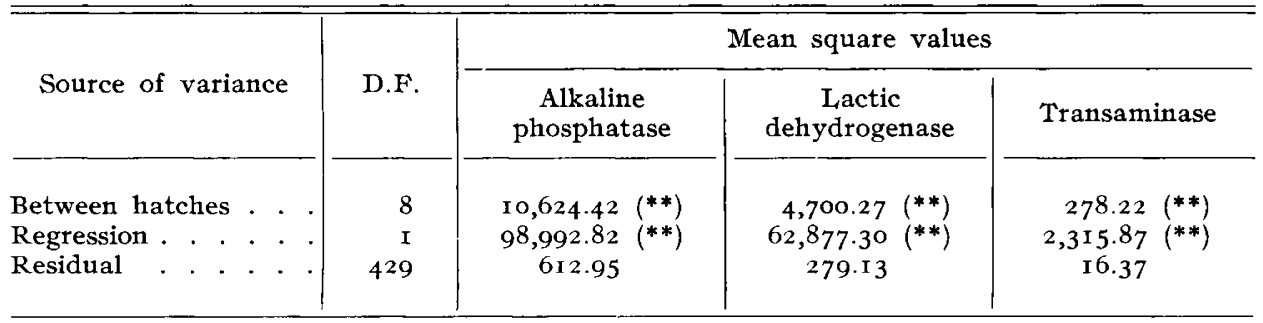

(**) Significant at the I p. roo level.

correlations involving this trait are imaginary. The heritability values of calcium, glucose and uric acid are very high, uric acid showing the highest estimate of 0.75 .

The genetic correlations among the five traits of Table 7 (that is; excluding inorganic phosphorus) are all positive except those involving calcium. Uric acid showed the highest genetic correlation with egg production $(+0.9)$, explaining more than $80 \mathrm{p}$. Ioo of its variance. Calcium, glucose and urea, the almost completely genetically correlated characters, showed genetic correlation values of more than 0.7 with egg production. 


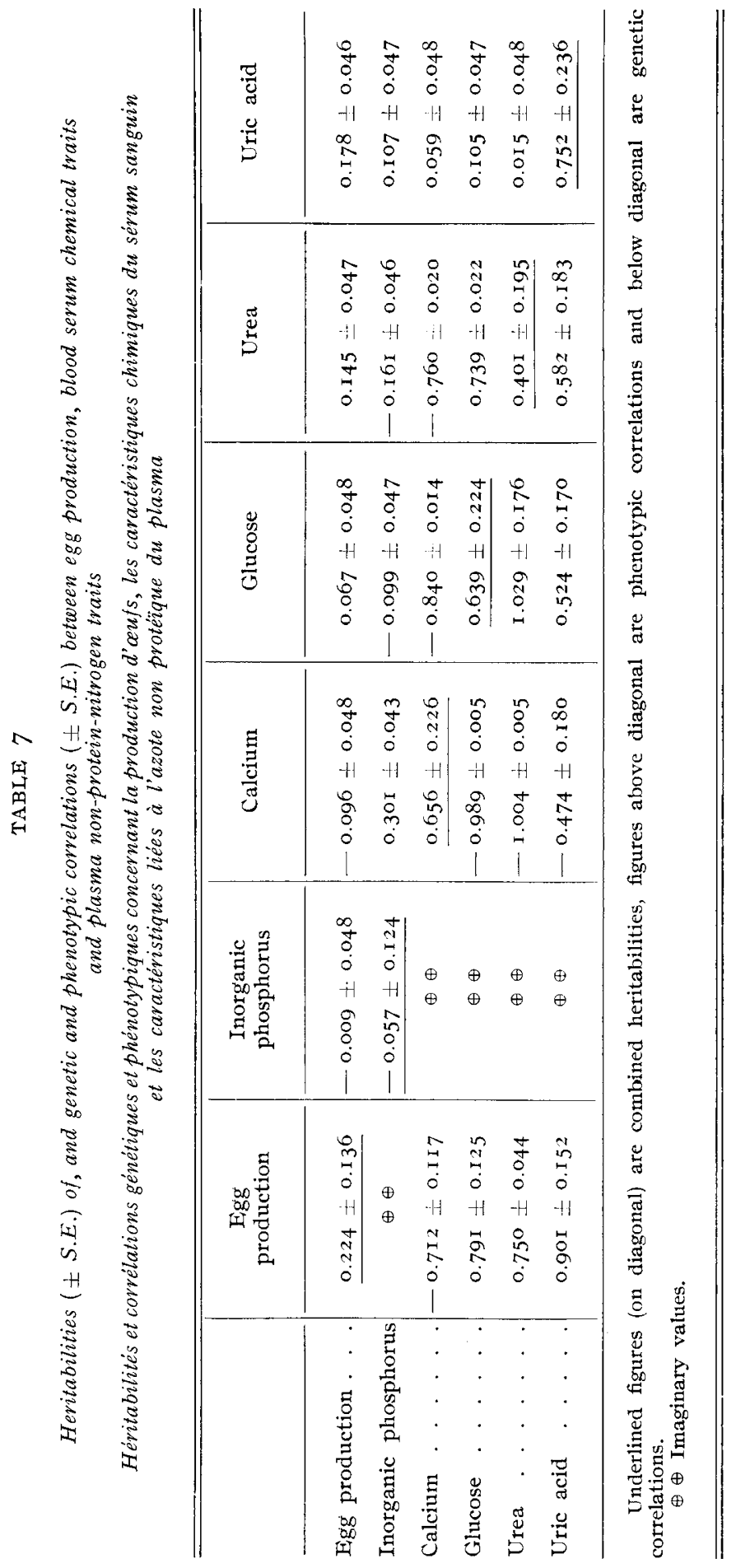


The phenotypic correlations among the six traits of Table 7 are less in size than the corresponding genetic correlations, though of the same signs. It can be observed that egg production had significant phenotypic correlations only with urea and uric acid. Calcium, glucose and urea showed again very high and significant phenotypic correlations among themselves.

\section{b) Egg production and group 2 of the serum traits:}

The heritabilities of the plasma proteins, cholesterol and bilirubin together with the genetic and phenotypic correlations among themselves and with egg production are given in Table 8 . Among this group of serum traits, albumen showed the highest and significant heritability value (of $0.56 \pm 0.2 \mathrm{I}$ ). Total proteins had the lowest value of heritability (0.II4 \pm 0.154$)$ and showed no significant genetic correlations with any of the characters studied, except bilirubin, with which the genetic correlation was complete (see also Tables 9 and II).

Bilirubin showed complete genetic correlations also with all the other characters of Table 8 , including egg production. Egg production had also very high genetic correlations with albumen (0.9) and cholesterol (o.8).

Phenotypic correlations of group 2 of the serum traits with egg production are all significant and have the highest value of 0.23 with albumen.

\section{c) Correlations between serum traits of group $I$ and group 2 :}

The genetic and phenotypic correlations between the serum traits of group I and those of group 2 are presented in Table 9. Total proteins, as discussed above, are not significantly correlated genetically with any of the serum traits of group $I$. So is also uric acid, except for its high genetic correlation with cholesterol (o.84 \pm o.II). Calcium showed significant negative correlations with all the serum traits of group 2, except total proteins. Albumen and bilirubin showed complete, or almost complete genetic correlations with calcium, glucose and urea. Cholesterol had complete genetic correlation with urea and was very highly genetically correlated with calcium and glucose.

The phenotypic correlations of calcium, glucose and urea with albumen, cholesterol and bilirubin are all significant; those involving albumen showed the highest values followed by those involving bilirubin. Inorganic phosphorus showed significant phenotypic correlations only with total proteins and cholesterol.

\section{d) Egg production and group 3 of the serum traits:}

The heritability estimates of the three blood serum enzymes studied are presented in Table Io, together with their genetic and phenotypic correlations, among themselves and with egg production. The blood serum enzymes had very high and significant estimates of heritability, alkaline phosphatase showing the highest heritability value of $0.73 \pm 0.23$. The estimate reported by WiLcox, VANVLECK and SHAFFNer (I962) for the heritability of alkaline phosphatase in the blood serum of 6-weeks old pullets $(0.36)$ is just half the value estimated here.

Alkaline phosphatase, lactic dehydrogenase and transaminase are completely or almost completely genetically correlated, lactic dehydrogenase being negatively 


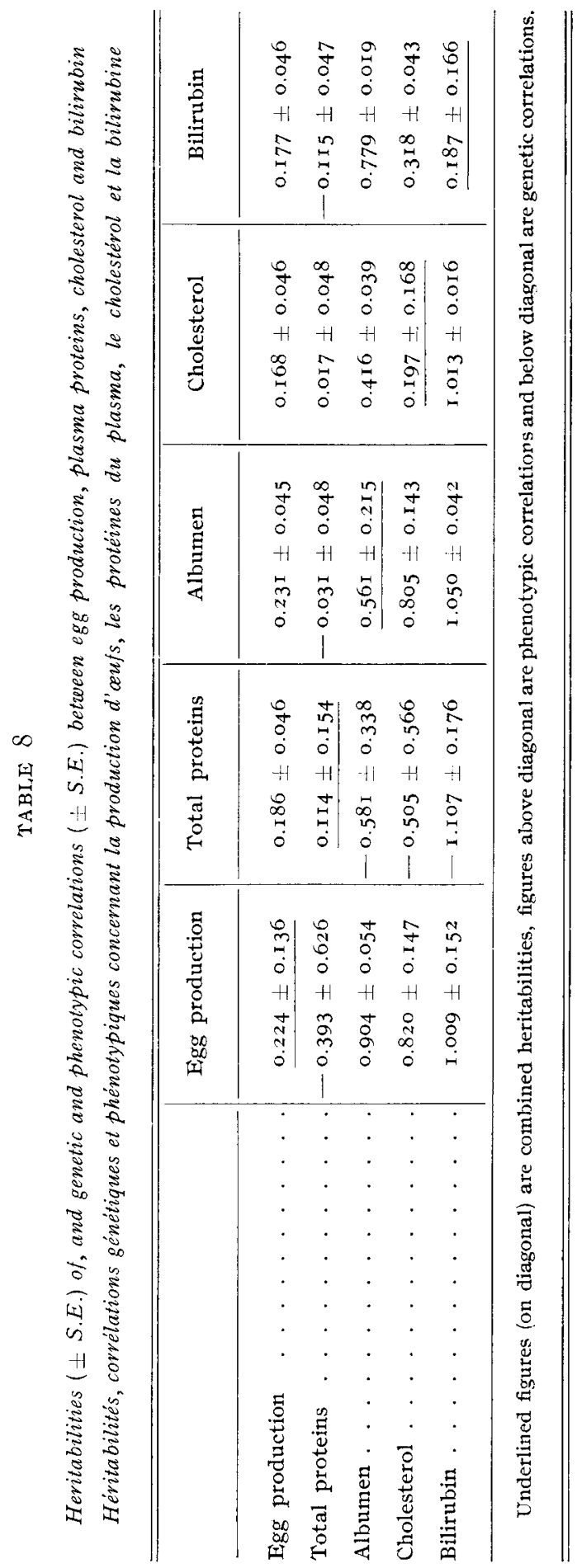




\section{TABIE 9}

Genetic and phenotypic corvelations (. S.E.) between plasma proteins, cholesterol and bilirubin and each of the serum chemical traits and plasma non-protein-nitrogen traits

Corrélations génétiques et phénotypiques entre les protéines du plasma, le cholestérol et la bilirubine et chacune des caractéristiques chimiques du sérum et de l'azote non protéique du plasma

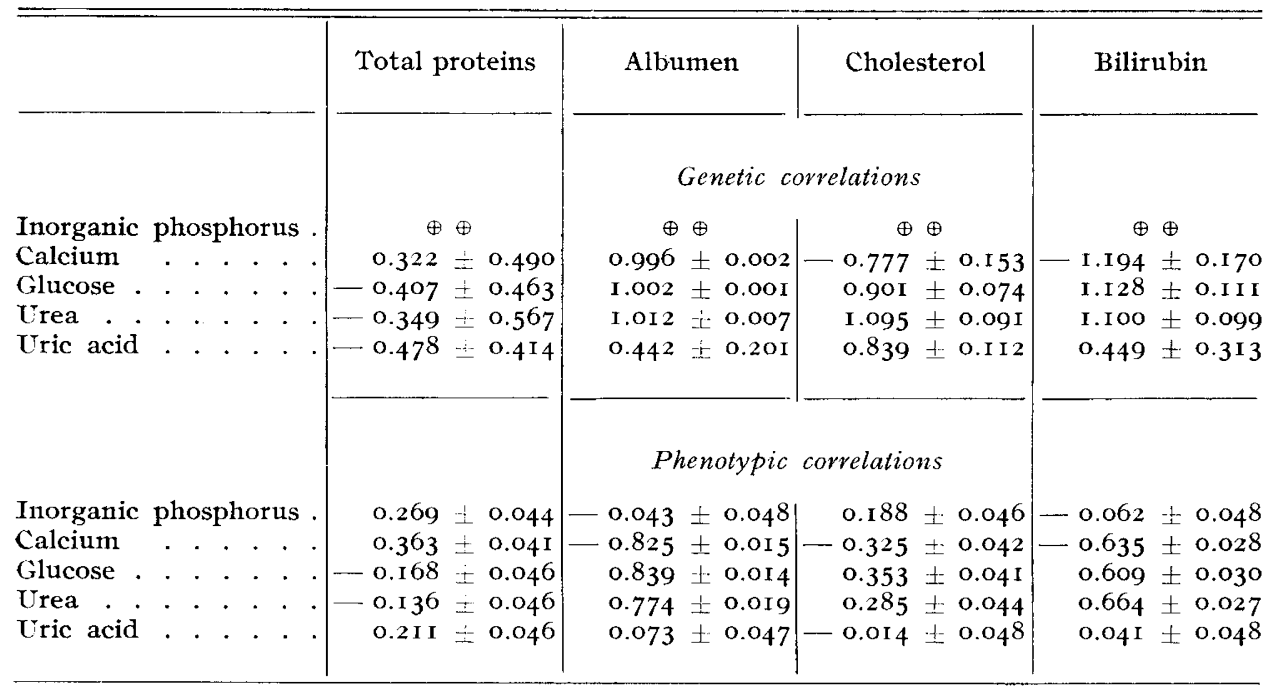

$\oplus \oplus$ Imaginary values.

TABLE IO

Heritabilities ( \pm S.E.) of, and genetic and phenotypic correlations ( $\pm S . E$. between egg production and the three plasma enzymes studied

Héritabilités, corrélations génétiques et phénotypiques concernant la production d'cujs et les trois enzymes plasmatiques étudiés

\begin{tabular}{|c|c|c|c|c|}
\hline & $\begin{array}{l}\text { Egg } \\
\text { production }\end{array}$ & $\begin{array}{c}\text { Alkaline } \\
\text { phosphatase }\end{array}$ & $\begin{array}{c}\text { Lactic } \\
\text { dehydrogenase }\end{array}$ & Transaminase \\
\hline Egg production . . . & $0.224 \pm 0.136$ & $0.137=0.047$ & $-0.089 \pm 0.047$ & $0.179 \pm 0.046$ \\
\hline Alkaline phosphatase & $0.847 \pm 0 . x 01$ & $0.732 \pm 0.234$ & $-0.807 \perp 0.017$ & $0.893 \pm 0.010$ \\
\hline Lactic dehydrogenase. & $-0.858 \leftrightharpoons 0.107$ & $-0.985 \pm 0.007$ & $0.625 \pm 0.223$ & $-0.786 \pm 0.018$ \\
\hline Transaminase & $0.799 \div 0.137$ & $1.023 \pm 0.01 \mathrm{I}$ & $-0.988 \pm 0.006$ & $0.622 \pm 0.222$ \\
\hline
\end{tabular}

Underlined figures (on diagonal) are combined heritabilities, figures above diagonal are phenotypic correlations and below diagonal are genetic correlations. 
correlated with the other two serum enzymes. The three enzymes are highly correlated genetically with egg production. The genetic correlations with egg production of alkaline phosphatase and transaminase were positive $(0.85$ and 0.80 resp.) and of lactic dehydrogenase was negative (- 0.86$)$. Wircox et al. (I962) reported a genetic correlation estimate of +0.5 between serum alkaline phosphatase level of 6 -week old pullets and their egg production. It may be noted that egg production in the present study showed significant negative genetic correlations only with calcium and lactic dehydrogenase. As described above, the means of these last two characters, unlike egg production, increased in the late hatches and with the advancement of age.

The phenotypic correlations between the three blood enzymes showed also high significant values of the same signs as the corresponding genetic correlations. Alkaline phosphatase and transaminase had very low but significant positive phenotypic correlation values with egg production. The correlation of lactic-

\section{TABLE II}

Genetic and phenotypic correlations ( \pm S.E.) between the three plasma enzymes and each of the serum chemical traits, plasma non-protein-nitrogen traits, proteins, cholesterol and bilirubin

Corrélations génétiques et phénotypiques entre les trois enzymes plasmatiques et chacune des caractéristiques chimiques du sérum, de l'azote non protéique du plasma, les protéines, le cholestérol et la bilirubine.

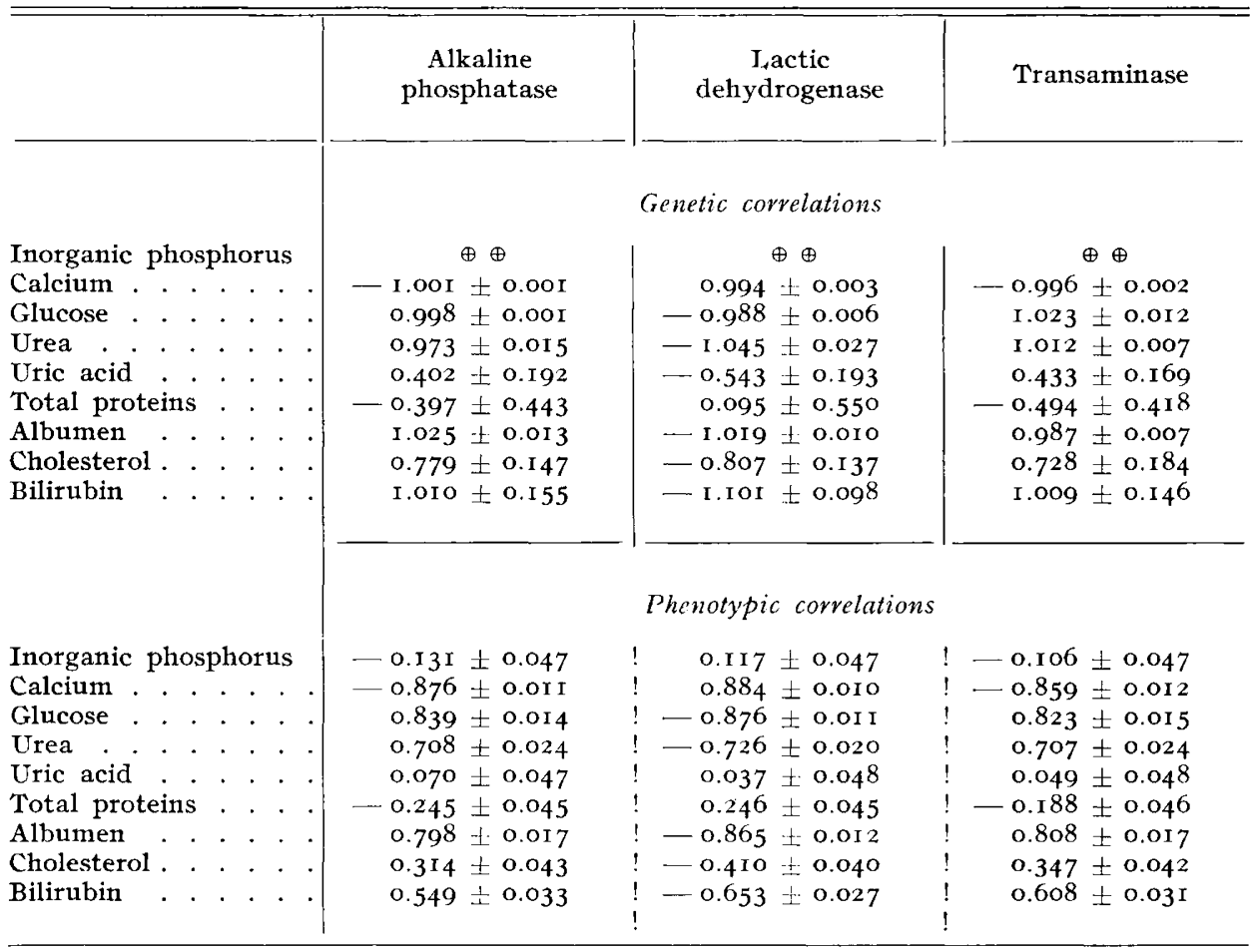

$\oplus \oplus$ Imaginary values. 
dehydrogenase with egg production was negative and insignificant $(-0.089$ $\pm 0.047)$. Wilcox et al. (I962) reported a phenotypic correlation estimate of o.or between egg production and serum alkaline phosphatase level.

\title{
e) Correlations between serum enzymes and serum traits of group $I$ and group 2 :
}

The genetic and phenotypic correlations between the three blood serum enzymes and each of the serum traits of group I and group 2 are presented in Table II. It can be seen, here also, that the genetic (or phenotypic) correlation of each of the different serum traits of group I or 2 with either alkaline phosphatase or transaminase has a different sign from the corresponding correlation with lactic dehydrogenase. All genetic correlations of any of the three enzymes with uric acid and total proteins are insignificant. Otherwise, all genetic correlations are significant. It can be noticed that the three correlations of any of the serum traits with the three enzymes are almost of the same magnitude. Calcium, glucose, urea, albumen and bilirubin have complete, or almost complete genetic correlations with the serum enzymes.

The phenotypic correlations are all of lower magnitudes compared to their corresponding genetic correlations, and are all significant except those involving uric acid. Inorganic phosphorus showed significant phenotypic correlations, though of very low magnitudes, with the three blood serum enzymes.

$$
\text { Rę̧u pour publication en avril } 1978 \text {. }
$$

\section{Résumé}

\author{
Paramètres génétiques et phénotypiques de la production d'ceufs \\ et de certains constituants du sérum sanguin chez des pondeuses Fayoumi
}

Un total de 439 pondeuses Fayoumi issues de 9 lots d'éclosion, d'un âge compris entre I 2 et 19 mois, ont été utilisées pour étudier (r) la production d'œufs; puis les constituants suivants du sérum sanguin : (2) phosphore inorganique, (3) calcium, (4) glucose, (5) urée, (6) acide urique, (7) protéines totales, (8) albumine, (9) cholestérol, (Io) bilirubine, (I I) phosphatase alcaline, (12) déshydrogénase lactique, ( 13 ) transaminase. Ces pondeuses étaient les filles de 40 pères et 24 I mères. Les analyses sur le sérum étaient faites à l'aide de l'auto-analyseur Séquentiel Multiple, SMA-1 2/6o. La moyenne estimée par les moindres carrés pour le nombre d'œufs produit par poule jusqu'à 70 semaines d'âge était 78 . Les moyennes des moindres carrés des paramètres du sérum sanguin mentionnés plus haut étaient dans l'ordre : (2) 5,55 $\mathrm{mg}$ p. I OO, (3) $2 \mathrm{I}, 62 \mathrm{mg}$ p. Ioo,

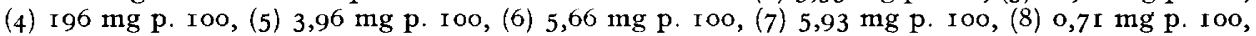
(9) I67,4 mg p. IOo, (IO) o,36 $\mathrm{mg}$ p. IOo, (I I) I $023 \mathrm{mu} / \mathrm{ml}$, (I 2) $667 \mathrm{mu} / \mathrm{ml}$, (I3) I69,7 $\mathrm{mu} / \mathrm{ml}$.

Le lot d'éclosion avait des effets statistiquement sigrificatifs sur tous les caractères étudiés excepté le phosphore inorganique, l'acide urique, les protéines totales et le cholestérol. L'âge de la poule affectait de façon significative tous les caractères du sérum sanguin excepté le phosphore inorganique, l'acide urique et les protéines totales.

Les données étaient corrigées pour l'effet du lot d'éclosion, et, dans le cas des caractéristiques du plasma, pour l'effet de l'âge, préalablement aux analyses hiérarchiques de variance et de covariance destinées à évaluer les héritabilités et les corrélations génétiques et phénotypiques. Les estimations combinées de l'héritabilité des caractères étudiés étaient dans l'ordre : (I) 0.224 $\therefore 0.136,(2)-0,057 \pm 0,124,(3) 0,656 \pm 0,226,(4) 0,639 \pm 0.224,(5) 0,401 \pm 0,195,(6) 0,752$

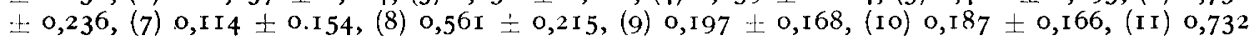
$\div 0,234$, (12) $0,625 \pm 0,223$, (13) $0,622 \pm 0,222$.

Des corrélations génétiques significatives (d'une valeur supérieure ou égale à $\pm 0,7$ ) étaient trouvées entre la production d'œufs et tous les caractères du sérum sanguin excepté le phosphore inorganique et les protéines totales. 


\section{Références}

Beli, D. J., FreEman B. M., I971. Physiology and Biochemistry of the Domestic Fowl. Academic Press.

Estep G. D., FAnguy R. C., Ferguson T. H., I 969. The effect of age and heredity upon serum cholesterol levels in chicken. Poult. Sci., 48, 1908.

Gutowska M. S., Parkhurst R. T., Parrot E. M., Veriurg R. M., i943. Alkaline phosphatase and egg formation. Poult. Sci., 22, 195-204.

HARVEY W. R., I960. Least squares analysis of data with unequal subclass numbers. ARS-20-8. United states Dept. of Agriculture.

Matsumoto K., Tonoue T., OKada I., i 960. Heritability of physiological characters of chickens. III. Serum alkaline phosphatase activity and its relation to growth. J. Fac. Agric. Hokkaido Univ., 51, 315-323.

McDaniel L. S., Chute H. L., ig6r. Enzymes activity in chicken plasma. Am. J. Vet. Res., 22, $99-103$.

OkADA I., Tsutsumi Y., 1963. Heritability of physiological characters of chicken. IV. Further studies on body weight, gain, serum alkaline phosphatase, and their relationships, using a diallel mating. Jap. J. Zoot. Sci., 34, I I4-120.

ShImer S. R., I937. Chemical studies on chicken blood. Univ. New Hampshive Tech. Bull., 69.

STURkIE P. D., I976. Avian Physiology. Third Edition. Springer Verlag, New York.

Sturkie P. D., NEwman H. J., I95I. Plasma proteins of chickens as influenced by time of laying, ovulation, number of blood samples taken and plasma volume. Poult. Sci., 30, 240.

TAPPER D. N., KARE M. R., 1960. Blood glucose distribution in the domestic fowl. Proc. Soc. Exp. Biol. Med., 103, 789-790.

WeIss J. F., Johnson R. M., NABER E. C., I967. Effect of some dietary factors and drugs on cholesterol concentration in the egg and plasma of the hen. J. Nutr., 91, II9.

Wilcox F. H., I966. Effect on performance of selection for high level of alkaline phosphatase in serum. Poult. Sci., 45, 776-784.

Wilcox F. H., VAN Vleck L. D., HaRvey W. R., I963. Estimates of correlations between serum alkaline phosphatase level and productive traits. Poult. Sci., 42, I457-I $45^{8}$.

Whicox F. H., Vanvleck L. D., Shaffner E. C., I962. Serum alkaline phosphatase and egg production. Proc. XII. World's Cong., Sydney, pp. I9-2z. 